CZU 327(410+478)

https://doi.org/10.52388/1812-2566.2020.4(91).06

\title{
SOFT POWER CONCEPT OF THE UNITED KINGDOM AND ITS REFLECTION IN THE REPUBLIC OF MOLDOVA
}

\author{
Cristina EJOVA \\ Doctor în științe politice, conferențiar universitar, Universitatea de Stat din Moldova, Facultatea Relaţii \\ Internaţionale, Științe Politice și Administrative, Chișinău, Republica Moldova \\ e-mail:doctorkb@mail.ru \\ https://orcid.org/0000-0003-3853-4262 \\ Master în stiințe politice, Universitatea de Stat din Moldova, Facultatea Relații Internaționale \\ Științe Politice și Administrative, Chișinău, Republica Moldova \\ e-mail: igorzaharov1996@gmail.com \\ https://orcid.org/0000-0001-8074-690X
}

This article explores the concept of soft power and its evolution in the United Kingdom of Great Britain and Northern Ireland in the 21st century. The concept of soft power, has gained widespread popularity in recent decades among both researchers and politicians and civil servants. The emergence and rapid development of this concept is due to scientific research conducted by the representative of the neoliberal school of international relations Joseph Nye, an American foreign policy specialist and professor at the John F. Kennedy School of Government at Harvard University. Thus, soft power can be defined as the political activity of state and public institutions and organizations, in the long run, both in traditional and modern diplomacy, designed to protect and achieve national interests, by creating a positive image of the state on the international arena and the formation in other countries of friendly and influential communities. The United Kingdom is the country that ranks first in most surveys and a paper conducted by renowned research institutes and has extensive experience in using soft power resources to promote the image of the state.

Keywords: soft power, public diplomacy, state image, national interest, United Kingdom, Republic of Moldova.

\section{CONCEPTUL DE SOFT POWER ÎN REGATUL UNIT AL MARII BRITANII ȘI REFLECȚIA ACESTUIA ÎN REPUBLICA MOLDOVA}

In prezentul articol este supus analizei conceptul de soft power și evoluția acestuia în Regatul Unit al Marii Britanii și Irlandei de Nord în secolul al XXI-lea. Conceptul de soft power sau putere blândă, capătă în ultimele decenii o popularitate largă atât în rândul cercetătorilor cât şi în cel al politicienilor şi funcţionarilor publici. Apariţia şi dezvoltarea rapidă al conceptului dat se datorează cercetărilor științifice, efectuate de reprezentantul școlii neoliberale a relațiilor internaţionale Joseph Nye, specialist american în domeniul politicii externe şi profesor la John F. Kennedy School of Government din cadrul Universităţii Harvard. Astfel, soft power poate fi definită ca activitate politică a instituțiilor și organizațiilor de stat și obștești, pe termen lung, atât în cadrul diplomației tradiționale, cât și al celei moderne, concepută pentru protecția și realizarea intereselor naționale, prin crearea unei imagini pozitive a statului pe arena internațională 
și formarea în alte țări a unor comunități prietenoase și influente. Marea Britanie este țara care ocupă primele poziții în majoritatea sondajelor și lucrărilor efectuate de renumite institute de cercetare și are o experiență bogată în utilizarea resurselor soft power in promovarea imaginii statului.

Cuvinte-cheie: soft power, diplomație publică, imaginea statului, interes național, Regatul Unit, Republica Moldova.

\section{LE CONCEPT DE SOFT POWER AU ROYAUME-UNI DE GRANDE-BRETAGNE ET SON REFLET EN RÉPUBLIQUE DE MOLDOVA}

Cet article traite du concept de soft power et de son évolution au Royaume-Uni de Grande-Bretagne et d'Irlande du Nord au XXIe siècle. Le concept de soft power, ou pouvoir doux, a acquis une grande popularité au cours des dernières décennies parmi les chercheurs, les politiciens et les fonctionnaires. L'émergence et le développement rapide du concept donné sont dus à la recherche scientifique, menée par le représentant de l'École néolibérale des relations internationales Joseph Nye, spécialiste américain dans le domaine de la politique étrangère et professeur à John F. Kennedy School of government à l'Université Harvard. Ainsi, le soft power peut être défini comme une activité politique à long terme des institutions et organisations étatiques et publiques, à la fois dans le cadre de la diplomatie traditionnelle et moderne, conçue pour la protection et la réalisation des intérêts nationaux, en créant une image positive de l'État sur la scène internationale et la formation dans d'autres pays La Grande-Bretagne est le pays qui occupe les premières positions dans la plupart des enquêtes et des travaux menés par des instituts de recherche célèbres et possède une riche expérience dans l'utilisation des ressources de soft power pour promouvoir l'image de l'État.

Mots-clés: soft power, diplomatie publique, image de l'état, intérêt national, Royaume-Uni, République de Moldova.

\section{КОНЦЕПЦИЯ МЯГКОЙ СИЛЫ В СОЕДИНЕННОМ КОРОЛЕВСТВЕ ВЕЛИКОБРИТАНИИ И ЕЕ ОТРАЖЕНИЕ В РЕСПУБЛИКЕ МОЛДОВА}

В данной статье исследуется концепиия мягкой сильь и ее эволюиия в Соединенном Королевстве Великобритании и Северной Ирландии в 21 веке. Концепция soft power или мягкой силь в последние десятилетия приобрела широкую популярность как среди исследователей, так и среди политиков и государственных служащих. Возникновение и быстрое развитие данной концепчии связано с научными исследованиями, проведенными представителем неолиберальной школь международных отношений Джозефом Най, американским специалистом по внешней политике и профессором Школь государственного управления Джсона Ф. Кеннеди при Гарвардском университете. Таким образом, мягкую силу можно определить как политическую деятельность государственных и общественных институтов и организаџий, в долгосрочной перспективе, как в традиционной, так и в современной дипломатии, направленную на защиту и достижение национальных интересов путем создания положительного имиджа государства на международной арене и формирование дружественных и влиятельных сообществ в других странах. Соединенное Королевство Великобритании занимает первые места в большинстве опросов и статей, проводимых известными исследовательскими институтами, и имеет богатый опыт использования ресурсов мягкой силы для продвижения имиджа государства.

Ключевые слова: мягкая сила, публичная дипломатия, имидж государства, наииональный интерес, Соединенное Королевство, Республика Молдова.

\section{Introduction}

The concept of soft power was found to be in demand not only in the native country of the author of the term, J. Nye, but also in many other countries of the world. Great Britain is no exception for this list. Today, the term soft power is widely used by British politicians, used in official documents of the government, parliament, in the scientific and expert 
community and in the media. For example, the National Security Strategy and Strategic Defence and Security Review [8], published in 2015, put a lot of emphasis on soft power: the need to strengthen British influence with soft power mechanisms is designated as one of the most important priorities of the national security strategy. The concept of soft power comes as an alternative to military force and economic pressure. This concept is a relatively new one that appeared in international usage in 1990 and was introduced by Harvard University professor Joseph Nye. Through the soft power strategy, J. Nye refers to the ability of an actor to influence other states in order to achieve their own goals through collaboration in certain areas aimed at persuasion and forming the positive perception globally.

\section{Main ideas of the research}

Traditionally, it was Britain that ranks among the leaders in the use of soft power in relation to other countries. According to one of the most influential ratings done by an international $\mathrm{PR}$ agency called Portland, from the University of Southern California, The Soft Power 30, the UK is on the 1st place in their annual report for 2018 and 2nd in the report for 2019 [1].

This rating considers several indicators, of which, as a result, the total score is determined, and thus, the country's place in this list is assessed. The following indicators are evaluated and analysed: digital technologies, entrepreneurship, education, culture, international engagement, management (government) and elections. The soft power resource objectively forms the basis for the continued success of the UK. For a long time, all of the above indicators remain at a high level, and compared with previous years, the total UK score for 2018 has become much higher. At the same time, we can see that last year, the UK was placed second in the report, most probably the score being affected by Brexit situation.
The main institutions responsible for directing the soft power of British foreign policy are undoubtedly government agencies such as the Foreign and Commonwealth Office, the Department for International Development, the Department for Culture, Media and Sport. However, these structures are not the only ones when it comes to the implementation of the soft power policy [10].

A separate area on which the British government focuses is the direct promotion of English language by providing support to learners and teachers around the world, as well as through a large number of activities, one way or another related to the study of English. Great Britain actively uses the historical advantages associated with the prevalence and popularity of its national language in the world. In the following article we analysed how the UK's soft power and public diplomacy strategies have shaped in the past 10-15 years and how all these are reflected in Republic of Moldova

Republic of Moldova and the United Kingdom have a long history of bilateral relationship based on mutual friendship and good will of the both states. The diplomatic relations between the two states were concluded on January 17, 1992. The Ambassador of the Republic of Moldova to United Kingdom of Great Britain and Northern Ireland is Ms. Angela Ponomoriov, while the British Ambassador to the Republic of Moldova is Mr Steven Mark Fisher (since September 2019) [1]. Unfortunately, there were not many official visits at high level. The main bilateral visits at the level of Heads of State took place in October 1996 - the working visit of President Mircea Snegur to the United Kingdom. In May 2014 took place the visit to Chisinau of Mr William Hague, Secretary of State for Foreign and Commonwealth Office of the UK [4]. The United Kingdom, together with its EU partners, recognised the independence of the Republic of Moldova on December 31, 1991. The British Embassy was opened in Chisinau in 
2002, and is currently developing and maintaining relations between the United Kingdom and the Republic of Moldova. The United Kingdom is a permanent member of the UN Security Council and a member of the G7, NATO, WHO and many other organisations, which demonstrates the influence and great power of this country.

During the 28 years since the establishment of diplomatic relations between the Republic of Moldova and the United Kingdom, there was a remarkable cooperation between both states, a period in which concrete results were recorded in various fields. The assistance provided by the United Kingdom to our country in its efforts to strengthen democratic institutions and to develop an environment conducive to sustainable and equitable economic growth is indisputable and has been growing since the beginning of it.

So far, there are 16 bilateral agreements signed between the Republic of Moldova and the United Kingdom in various areas, such as: political, economic, security, etc. [3]. Speaking about the judicial background, we have to say that Brexit has influenced British cooperation with the Republic of Moldova. It is obvious that when all British government structures are primarily concerned with the issue of Brexit, it is more difficult to make yourself heard when trying to promote bilateral cooperation in various fields. At the same time, we can say with certainty that collaboration between our countries continues to deepen, and in order to ensure that this pace is maintained even after Britain left the European Union, Moldova is currently in talks with British colleagues to identify a suitable formula for the appropriate legal framework, which will underpin bilateral relations between the Republic of Moldova and the United Kingdom after the transition period between the UK and EU is over. The bilateral treaty that will be negotiated has a special importance, because it is going to replace the Association Agreement between the Republic of Moldova and the European Union in the relations between our two countries. At the moment, the negotiation of the Political Partnership and Trade Agreement is taking place, which will transpose the provisions of the Moldova-EU Association Agreement. These provisions will be applied bilaterally and will include both the political and the economic and free trade components, increasing the clarity of legal regulations and facilitating their implementation [5].

The economic dimension is an important one in Moldovan-British relations, the United Kingdom being one of the country's main trading partners. The main economic agreement signed between the Republic of Moldova and the United Kingdom are: Agreement between the Government of the Republic of Moldova and the Government of the United Kingdom of Great Britain and Northern Ireland on the promotion and mutual protection of investments, signed in London in 1996. According to statistics, the volume of trade between the Republic of Moldova and the United Kingdom of Great Britain and Northern Ireland has had a general upward trend over the last 15 years (except for a few years, including last year, when bilateral trade was smaller compared to previous years). During the mentioned period, the United Kingdom was placed in the list of the most important trading partners of the Republic of Moldova, occupying in 2016-2017 the 5th position after the volume of exports from the Republic of Moldova, and in 2018, as - the 8th position [1]. Imports into the Republic of Moldova from the United Kingdom have also been significant. The Republic of Moldova imports cars and other vehicles, medicines, personal hygiene products, perfumery, cosmetics, etc. Land Rover and Jaguar cars are emblematic figures in the UK's soft power and public diplomacy.

According to the Report of the consulting organisation „British Enterprise” created at the request of the British Foreign and Commonwealth Office, the 
most important and wanted investment opportunities for British companies in the Republic of Moldova are in the following sectors: energy, in particular energy efficiency and alternative energy sources; agribusiness (including irrigation systems and water resources); education and training; training in the areas of public administration, including justice, taxes and customs; information and communication technologies; infrastructure projects; light industry, especially the textile industry.

Another problem present in the MoldovanBritish dialogue is the Transnistrian issue, which, beyond the security risks for the whole region, is an obstacle in the development of the country and in attracting British investors. In this regard, the officials from Foreign and Commonwealth Office promised assistance and expertise for the Republic of Moldova in the process of settling the dispute, taking into account the experience of Great Britain in this field. These promises have shaped into concrete actions by establishing a new fund - Conflict Security and Stability Fund (CSSF) which was created in 2015. The British Government created the CSSF on 1 April 2015, replacing the previous Conflict (Prevention) Pool [11]. It is a pool of money, over $£ 1$ billion pounds per year, for tackling conflict and instability overseas. It is part of the government's official development assistance. In Moldova, through this programme was funded more than 10 projects. Here we can mention some of them: Vzlyot Summer School for young generations from both banks of Nistru River; Domestic Violence Shelters in Tiraspol; Fire-engine donations for both Chisinau and Tiraspol; British Council activity on both banks of the Nistru; destruction of pesticides project etc.

The technical assistance of the UK in the Republic of Moldova has been provided since 1991, through the Department for International Development (DfID). In 2000, DfID opened a permanent office in the Republic of Moldova. Until 2004, most assistance projects were carried out in the agricultural, banking and social sectors. In accordance with the Regional Assistance Plan for 2004-2007, projects have been carried out in the following areas: (1) improving governance and the institutional framework for poverty reduction; (2) promoting sustainable economic development; (3) strengthening the UK's contribution to conflict prevention and resolution. Through the Global Fund for Conflict Prevention, created jointly with the British FCO, the Ministry of Defence and DfID, a 3-year project was developed, called the Peace Insurance Framework, aimed at reducing poverty through conflict resolution, media training and interpersonal projects. After 11 years of activity in Moldova, DfID adopted the decision to end its activity in Moldova in March 2011 due to the fact that according to the OECD assessment, Moldova was promoted to the category of middle-income countries [4].

As of April 18, 2016, the Republic of Moldova benefits from British assistance through the Good Governance Fund (GGF). The funds are redirected to reform the most sensitive sectors, including the fight against corruption, improving the business environment, reforming the judiciary, the financial-banking sector, energy, strengthening public administration, etc. In the period 2016-2017, projects funded by the British Government, for which over 5 million euros were allocated, included [12]:

Assistance for the new Shareholder Transparency Monitoring Department created at the National Bank of Moldova for establishing the internal activity procedures of the structure;

Strengthening the capacities of the State Fiscal Service of the Republic of Moldova;

Assistance for the development of the Regional Development Agency recently created in Gagauzia;

Providing analytical support for an optimal fiscal system; 


\section{res;}

Responsible management of public expenditu-

Deep and Comprehensive Free Trade Agreement public information campaign;

Consolidation of a democratic regional media, which involves organizing and conducting TV debates in the local media (implemented in partnership with IPRE - Institute for European Policies and Reforms).

Moldovan-British relations are also developing in the socio-cultural field. Thus, the relations between the Republic of Moldova and the United Kingdom are fortified through different educational and academic programmes, such as: Chevening Scholarship [14]; John Smit Trust Fellowship and International Leaders Programme. Chevening Programme is the most important academic British project in Moldova. Chevening is UK Government scholarships and fellowships that enable future leaders to study in the UK, whilst joining a global community of professionals who are creating positive change around the world. The programme is being implemented in Moldova since 1993, and this year the British Embassy is about to select the 100th Chevening scholar who will pursue his or her Master Degree at one of the finest universities in the world.

Chevening has a large and influential alumni community in Moldova. In 2019, one of the Moldovan Chevener Alumnus became the one of the youngest MP (member of Moldovan Parliament) and the first Roma national to succeed in Parliament. His name is Radu Marian MP.

In 2017, the John Smith Trust Fellowship Program was resumed in the Republic of Moldova. The total value of this programme rises at 980,000 thousand pounds. We have some notorious alumni of John Smith Trust Fellowship who held different governmental positions: Andrei Popov, Ambassador, former vice-minister of Foreign Affairs; Iulian Fruntaşu, former Moldovan Ambassador to the UK;
Vladislav Kulminski, former adviser to the PM in Sandu's cabinet etc.

British education is one of the most significant resources of the national soft power, which is recognized both at home and abroad. This resource has been accumulating over a long period of time: for example, Oxford and Cambridge universities were founded as early as the 13th century and even today are among the top ten universities in the world according to the Times - they occupy 2 nd and respectively 4th places). In the first hundred of this rating, there are 16 British universities. It should be noted that while promoting British education abroad, not only history and traditions are emphasised, but also the modern advantages of British education, including achievements in the field of innovation, creative industries, high technologies etc.

According to the report of the House of Lords, in 2013 in the UK, at educational institutions of all levels, 435,000 students from abroad were enrolled. At the same time, according to estimates by the Department of Business, Innovation and Professional Training, from 2003 to 2013, British universities graduated about 2 million foreigners, the vast majority of whom returned home after completing their studies. According to the same department, over the next ten years (i.e. from 2013 to 2023), there will already be 3 million such graduates.

Graduates of British universities are seen by experts and the government as an important element of the country's soft power. For example, the Chevening scholarship program is aimed at supporting future leaders and those who will make decisions and influence in their countries around the world. The scholarship is designed to support their professional growth and help build long-term relationships with the UK [2].

Creativity is at the central of the UK's cultural diplomacy. The idea of creative industries played an important role in shaping contemporary political 
discourse. The state's interest in promoting creative industries abroad was reflected in the activities of key soft power institutions. At the same time, as follows from most strategic documents on this topic, government structures have a supporting role. In accordance with the general trend in the late 1990s - early 2000s, British Council focused on contemporary areas of art and represented British design, contemporary British artists, cinema and animation, and so on. In addition to the British Council, the Department of Culture, the Media and Sports plays a significant role in soft power government policy and promoting culture abroad. However, experts point out that the distribution of powers between the ministry and the British Council is not clearly defined and recommend that the leadership of these departments take a more strategic approach to planning their work and identifying areas of responsibility. In general, the department is more focused on supporting the overseas activities of representatives of British creative industries [6].

Science and innovation are another area that plays an important role in the country's soft power policy. The role of science and innovation for soft power, as is the case with other priority areas for the implementation of such a policy, is multidimensional. The names of the author of the theory of evolution, Charles Darwin, one of the founders of classical physics, Isaac Newton, the founder of the idea of the electromagnetic field, Michael Faraday, discoverer of penicillin Alexander Fleming and many other great British people are known around the world and still influence ideas about Britain and increase the country's attractiveness for tourists, highly qualified specialists and scientists. British scientists have become Nobel Prize winners more than 100 times [13]. Speaking about the new industrial strategy of Great Britain in May 2018, the country's Prime Minister Theresa May mentioned many great scientists of the past. At the same time, much attention is paid to the modern scientific achievements of Great Britain. So, in the same speech, T. May mentions the discovery of graphene, British developments in areas such as gene therapy, magnetic resonance imaging, etc.

If to talk about activities aimed at promoting international development - they represent one of the most important tools to increase the soft power of the United Kingdom: it not only contributes to the formation of a positive image and increase the attractiveness of the country, but also allows the introduction of British (and in a broader sense, Western) values, norms and models behaviour in recipient countries. For example, some British authors, and now after the Brexit has finally happened, even on official level, the politicians argue about the possibilities of Great Britain to act and position itself as a kind of "force for good" in the world, in essence developing the idea of post-imperial messianism of England .

The House of Lords Committee on soft power and influence of Great Britain believes that the distribution of aid allows the UK to build ties with ordinary citizens and with the national governments that are assisted, as well as with foreign audiences in general, and contributes to creating a positive image of a generous and beneficial country with whom governments should build good relations. This is not only about increasing the influence in recipient countries of aid, but also about the perception of Britain in the world as a whole. The document notes that international development assistance programs help promote British values and culture abroad, but should also take into account the values and culture of other countries and, if possible, be combined with them. In addition, experts believe that cooperation with the United Kingdom in the framework of assistance programs allows developing trade relations and promoting the country's image as a reliable partner.

Today, after the UK is no longer the member of the European Union, as the British people decided so 
in June 2016, the government is trying to formulate a new vision of the country's foreign policy under the guise of „Global Britain.” The memorandum of the FCO on this issue refers to the country's leadership in solving global problems and the significance of achievements in the field of science and innovations for the country's soft power. Among the key tasks of the FCO is to ensure global influence. It is proposed to increase it with the help of soft power based on the attractiveness of science, culture and education. Positioning the UK as one of the world leaders in science and education, as well as promoting the English culture and language, are the tasks of the British Council [9].

In 2001, the government initiated the creation of the UK Science and Innovation Network. It works with the support of the FCO and the Department of Business, Innovation and Skills and currently unites about 90 employees in different countries [7]. One of the goals of the network is ,to closely connect science with foreign policy priorities". Its employees usually work in embassies and consulates of the United Kingdom abroad. The network currently covers about 40 countries, including 16 in Europe. The network staff analyses the current situation in the host country in terms of scientific and innovative potential and opportunities for cooperation with the UK; participates in the coordination of joint projects and grant programs; supports the work of bilateral scientific commissions and other diplomatic initiatives; interacts with the representations of British organisations in these states.

In order to have a really up-to-dated work on the UK's soft power policy, we would like to present some information and statistic data on the UK's international response amid novel Coronavirus, Covid19 pandemic, as per 8 April 2020. This is showing the science and innovation aspects of the UK's soft power, as described above. According to many scientists and SAGE group - The Scientific Advisory
Group for Emergencies - which provides ministers and officials with evidence-based scientific advice in emergencies, the novel Coronavirus pandemic is the biggest public health emergency in a generation. It calls for decisive and coordinated actions, at home and abroad, guided by WHO (World Health Organisation) and based on science and evidence. The UK committed to donate up to 544 million pounds of UK aid funding to support global efforts to combat the outbreak of Covid-19. This includes a 71 million pounds announced for the research of vaccines and diagnostic tests.

A very important role in the UK's soft power influence in Republic of Moldova has the activity of the British charities. There are around 50 UK charities in Moldova who are working in different fields. For example, in Health and Medical Care, we have Tony Hawks Centre (children with severe disabilities), Hospice of Hope Moldova (terminally ill patients), MAD-Aid (children with severe disabilities). Children and De-institutionalisation: LUMOS Moldova and Copil Comunitate Familie/Hope and Homes for Children UK, who are also partners of central and local Government in implementing various reforms in these fields. Specific social issues are targeted by the following UK organisations: Help Age International, World Jewish Relief and The Salvation Army. Grass-roots groups that are carrying out activities at local level in remote villages, usually helping vulnerable children families, by organising summer camps, offering humanitarian aid, renovating facilities, such as Blythswood Care (mainly Nisporeni and Calarasi), Telecoms Eastern European Challenge (TEECH).

Another notable achievement of the UK soft power, here, in the Republic of Moldova was the participation of a team of cadets of the Military Academy of the Armed Forces „Alexandru cel Bun” in the International Military Patrol Exercise „Cambrian Patrol 2018", which traditionally took place in Octo- 
ber in the country of Wales, bringing together participants from 35 countries. It is important to mention that the Moldovan military won the silver medal, which can be described as an impressive performance, given that they participated in this Exercise only for the second time. The presence of our military at the event was possible thanks to the good cooperation established between the Ministry of Defence of the Republic of Moldova and the Ministry of Defence of the United Kingdom, which has intensified considerably recently. An additional confirmation of this fact is the appointment, last year, of the first military attaché at the British Embassy in Chisinau [12].

We can conclude that the UK has a strong and friendly relationship with Moldova, based on mutual respect and good will of both countries. The UK is one of the main donors for media development in Moldova and for financial sector reform in the country. The UK's soft power has reached Moldova as well, especially due to its attractiveness for Moldovan workers. In this context, we have to say that we have a very large diaspora in the UK, placing this country on the second place with number of Moldovans after Italy and Russia, with an approximate number of 70000 Moldovans living and working in the UK [3]. The UK has not forgotten about Moldova during the Covid-19 pandemic. On 3 May 2020, the Moldovan Ministry of Defence received a batch of protective equipment from the British Embassy in Chisinau, and specifically from Defence Section. The donation, worth over 18 thousand pounds, the equivalent of about 388 thousand lei, contains 8,000 surgical masks, 10,000 cotton masks, 2,000 litters of disinfectant, 20 infrared thermometers, 1,000 of protective coveralls and 10,000 pairs of nitrile gloves. According to the British Defence Attaché, Squadron Commander Rob Hall, the equipment was provided at the request of the defence institution of the Republic of Moldova, as well as in the context of colla- borative relations between the United Kingdom and the Republic of Moldova, both in the security and defence sector and other areas. Staying on the same path, we should also say that BBC Media Action, the charitable arm of the UK's public broadcaster, BBC, has produced a special Guide for Media with information and tips on how to work during Public Health Emergencies. The guide is available in Romanian and Russian languages and was distributed to media outlets and several state institutions, including the Audio-Visual Council.

Speaking of Covid-19 pandemic, the UK has also confirmed on 29 April that it will be the largest supporter of the international alliance to vaccinate children against deadly diseases, saving millions of lives. International Development Secretary AnneMarie Trevelyan announced a funding pledge equivalent of $£ 330$ million a year over the next five years to Gavi, the Vaccine Alliance, which will help fund immunisation of 75 million children in the world's poorest countries [1]. Eventually, this fund will help Moldovan people to get the necessary vaccines as well.

\section{Conclusions}

Summarising, we can clearly state that there are many programmes in which the UK is investing here, in Moldova through different governmental funds such as Good Governance Fund, Conflict Stability and Security Fund; International Programme etc. An important role in the UK's influence in our country has to play British educational programmes such as Chevening and John Smith Trust Fellowship. All these contributed to a highly qualified civil servants in different domains, including the diplomatic service, media sector, banking and financial sector etc. Clearly, there is a big unexplored potential for the development of the relationship between our two countries, especially on the commercial and cultural sides. Now, that the UK has left the EU, the new 
agreements are being negotiated by the both parts with hopes that our bilateral relationship will take a step forward.

\section{Bibliography}

1. Ambasada Marii Britanii la Chişinău menţine şi dezvoltă relaţiile dintre Marea Britanie şi Republica Moldova, https://www.gov.uk/world/organisations/britishembassy-chisinau.ro (accesat 01.05.2020)

2. BLONF, P., NOYES, J., Sin D. Britain's Global Future: Harnessing the soft power capital of UK institutions. London: Respublica, 2017. 40 p.

3. Cum va influența Brexit-ul viața moldovenilor din Regat. Explică Ambasadorul, https://www.moldova.org/ cum-va-influenta-brexit-ul-viata-moldovenilor-din-regatexplica-ambasadorul/ (accesat 01.05.2020)

4. EJOV, A. Soft power în formarea imaginii statului pe arena Internațională. În: Materialele Conferinței ştiințifice internaționale dedicate celei de-a 20 -a aniversări a Facultăţii Relaţ̧ii Internaţionale, Ştiințe Politice şi Administrative. USM 2015. p. 508-516.

5. Foreign and Commonwealth Office. Single departmental plan: 2015 to 2020, https://www.gov.uk/government/publications/fco-single-departmental-plan-2015-to2020/single-departmental-plan-2015-to-2020\#2 (accesat 01.04.2020).
6. ILGEN, Th. Hard Power, Soft Power and the Future of Transatlantic Relations.Washington: Pitzer College, Routledge, 2006. 203 p.

7. MARTEMS, K. Culture and Foreign Policy - A Comparative Study of Britain, France and Germany. University of Bremen. Germany. 2005, 12 p.

8. NYE, J. Bound to Lead: The Changing Nature of American Power. New York: Basic Books, 1990. 336 p.

9. NYE ,J. Soft Power: The Means To Success In World Politics. New-York: Public Affairs, Political Science, 2005. $191 \mathrm{p}$.

10. PAMMENT, J. British Public Diplomacy and Soft Power Diplomatic Influence and the Digital Revolution. Lund University: Palgrave Macmillan, 2016. 243 p.

11. Persuasion and Power in the Modern World: House of Lords Paper 150 Session 2013-14. S.1., Stationery Office. 2014, p. 106.

12. Soft power and the UK's influence committee. Oral and written evidence. Vol. 2. House of Lords, London, 2014, p. 747-749.

13. The English effect. The Impact of English, what it's worth to the UK and why it matters to the world. London: British Council, 2017, p. 8

14. Topul celor mai bune universităti din lume în 2020 la care ai putea să-ți faci studiile, https://diez. md/2020/01/27/topul-celor-mai-bune-universitati-dinlume-in-2020-unde-ai-putea-sa-iti-faci-studiile/ (accesat 01.04.2020). 